\title{
PENGARUH STRATEGI GENIUS LEARNING TERHADAP HASIL BELAJAR SISWA PADA MATERI FISIKA TOPIK LISTRIK DINAMIS KELAS IX SMP SWASTA RAKSANA MEDAN
}

\author{
Rita Juliani dan Fitri Meliana \\ Jurusan Pendidikan Fisika, FMIPA, Universitas Negeri Medan
}

\begin{abstract}
Abstrak. Genius Learning menggunakan gaya belajar yang berdasarkan pendekatan preferensi sensori dan profil kecerdasan (multiple intellegence). Penerapan strategi Genius Learning, berangkat dengan satu keyakinan dan pengharapan bahwa apabila setiap anak didik dapat dimotivasi dengan tepat dan diajar dengan cara yang benar yang menghargai keunikanya maka semua dapat mencapai suatu hasil pembelajaran yang maksimal. Hasil yang diperoleh terdapat perbedaan yang signifikan antara hasil belajar siswa yang diajarkan genius learning di kelas eksprimen dengan kelas yang diajarkan konvensional di kelas kontrol pada materi pokok fisika topik listrik dinamis di kelas IX SMP Swasta Raksana Medan Tahun Pelajaran 2009/2010. Ini berarti ada pengaruh strategi genius learning di kelas eksperimen yang memberikan hasil belajar yang lebih baik.
\end{abstract}

Kata kunci: strategi genius learning, hasil belajar, listrik dinamis

\section{THE EFFECT OF GENIUS LEARNING STRATEGY FOR STUDENT LEARNING OUTCOMES IN A DYNAMIC ELECTRICAL SUBJECT MATTER PHYSICS CLASSES IX SMP SWASTA RAKSANA MEDAN}

\author{
Rita Juliani and Fitri Meliana \\ Department of Physics Education, Science Faculty, State University of Medan
}

\begin{abstract}
Genius learning to use learning styles based approach to sensory preferences and profiles intelligence (multiple Intellegence). Application of Genius Learning strategy set out with the belief and hope that if any of the students can be motivated by the right and taught in the right way that respects keunikanya then all can achieve maximum learning outcomes. The results obtained are significant differences between the learning outcomes of students who are taught genius learning in the classroom experiment with classes taught in the conventional control class in the subject matter physics topic of dynamic power in SMP Swasta Raksana Medan class IX Academic Year 2009/2010. This means there is the influence of genius learning strategies in the classroom experiments that provide better learning outcomes.
\end{abstract}

Keywords: strategi genius learning strategy, learning outcomes, dynamic electrisity 


\section{PENDAHULUAN}

Banyak cara dan upaya yang dilakukan pemerintah untuk memperbaiki mutu pendidikan tersebut, baik dari proses pembelajaran maupun seluruh perangkat yang menyokong terlaksananya pendidikan seperti: sertifikasi guru-guru, perbaikan kurikulum serta bantuan sarana dan prasarana pendidikan. Pada kenyataannya pendidikan Indonesia menunjukkan fakta yang kurang menggembirakan dibanding dengan Negaranegara lain. Seperti terungkap dari fakta yang mendukung yaitu dalam laporan Badan Perserikatan Bangsa-Bangsa (PBB) untuk bidang pendidikan pada bulan Desember 2007, United Nation Educational, Scientific, and Cultural Organization, menunjukkan peringkat Indonesia dalam hal pendidikan turun dari 58 menjadi 62 di antara 130 negara di dunia (Pandia, 2008).

Pendidikan erat kaitannya dengan sains dan teknologi terutama pelajaran fisika. Selama ini siswa menganggap pelajaran fisika adalah hal yang membosankan bahkan menakutkan. Siswa masih menganggap fisika sulit, hanya berhubungan dengan angka-angka dan rumus. Kebanyakan siswa mengeluhkan bahwa mata pelajaran fisika sangat sulit dan kurang menyenangkan.

Kebosanan mempelajari fisika di dalam kelas dan menganggap fisika itu rumit ternyata dialami oleh siswa-siswi di SMP Swasta Raksana Medan. Berdasarkan studi pendahuluan yang dilakukan dengan memberikan angket kepada siswa diperoleh, dari 40 orang siswa, 27 orang siswa menganggap pelajaran fisika itu sulit dan kurang menyenangkan, sedangkan untuk kegiatan belajar mengajar fisika di kelas, 18 orang siswa berpendapat kegiatan belajar mengajar fisika di kelas membosankan dan sulit dipahami. Berdasarkan hasil angket ke kelas di dapat kesimpulan bahwa proses pembelajaran di kelas yang selama ini berlangsung masih monoton, guru menerangkan materi, siswa mencatat kemudian mengerjakan soal.

Berdasarkan angket yang diberikan kepada guru Fisika SMP Swasta Raksana yang menyatakan bahwa masih banyak siswa kurang semangat belajar fisika, dan metode yang selalu di pakai ketika mengajar adalah metode konvensional. Dari hasil angket siswa dan angket guru diketahui bahwa kegiatan belajar mengajar di kelas adalah masih monoton, guru menjelaskan materi, siswa mencatat dan kemudian mengerjakan soal-soal. Hal ini membuat suasana pembelajaran fisika terlihat kurang semangat, pemahaman siswa terhadap konsep yang diajarkan sangat dangkal.

Kurangnya interaktif dan variasi dalam belajar mengajar akan mengakibatkan kebosanan dan mengurangi minat siswa dalam mempelajari fisika berdampak pada nilai yang diperoleh siswa. Berdasarkan data yang diperoleh dari sekolah, dimana nilai fisika semester ganjil T.A 2008/2009, nilai terendah 30, nilai tetinggi 80 , nilai rata-rata 50 , hal ini menunjukkan bahwa nilai fisika belum mencapai standar ketuntasan yakni 60.

Beberapa upaya yang telah dilakukan oleh guru dalam mengatasi masalah belajar adalah dengan cara memvariasikan metode belajar yaitu dengan memberikan tugas-tugas kepada siswa dengan harapan siswa akan termotivasi mencari dan menemukan sendiri jawaban untuk setiap tugasnya. Selain itu, guru juga mencoba untuk memberikan pretes kepada siswa sebelum memulai pelajaran, dengan harapan siswa akan termotivasi untuk belajar terlebih dahulu di rumah agar semakin memahami materi yang akan dipelajari.

Namun, beberapa usaha yang dilakukan oleh guru tersebut belum juga dapat menjawab masalah yang terjadi dalam proses belajar fisika. Oleh karena itu diperlukan suatu cara memotivasi siswa untuk mau belajar, upaya yang dapat dilakukan guru yaitu menggunakan strategi mengajar yang membuat suasana belajar menjadi lebih menyenangkan sehingga mampu memotivasi siswa untuk belajar. Dalam hal ini guru sebagai perancang pengajaran perlu mengadakan pola pendekatan yang tepat untuk membantu siswa dalam belajar aktif serta dapat memahami konsep-konsep fisika yang diajarkan.

Salah satu alternatif yang dapat dilakukan untuk meningkatkan minat dan motivasi siswa mempelajari fisika dengan baik adalah dengan 
mengubah suasana pembelajaran yang melibatkan siswa dan menghadapkannya terhadap model pembelajaran yang menarik. Peranan guru sangat penting dalam memberikan dorongan untuk melakukan aktivitas tertentu agar tercipta tujuan yang diharapkan (Sardiman, 2007) menyatakan bahwa: guru harus dapat merangsang dan memberikan dorongan serta reinforcement untuk mendinamisasi potensi siswa, menumbuhkan swadaya (aktivitas) dab daya cipta (kreativitas), sehingga akan terjadi dinamika didalam proses belajar mengajar.

Guru harus menciptakan atau menerapkan strategi yang dapat mengaktifkan siswa belajar dan mampu memberi semangat bagi siswa dengan memilih strategi yang tepat dalam proses belajar mengajar. Dengan menggunakan strategi pembelajaran yang tepat maka akan memperoleh hasil belajar yang optimal.

Gunawan menawarkan satu strategi dengan pendekatan praktis dalam pembelajaran, yaitu strategi Genius Learning. Strategi Genius Learning adalah sebuah strategi dengan pendekatan yang praktis dalam pembelajaran. Gunawan (2006) mengungkapkan, dalam menerapkan strategi Genius Learning, kita berangkat dengan satu keyakinan dan pengharapan bahwa apabila setiap anak didik dapat dimotivasi dengan tepat dan diajar dengan cara yang benar yang menghargai keunikan mereka maka mereka semua dapat mencapai suatu hasil pembelajaran yang maksimal. Genius Learning adalah istilah yang digunakan untuk menjelaskan rangkaian pendekatan praktis dalam meningkatkan hasil proses pembelajaran yang memiliki delapan tahap pembelajaran. Genius Learning ini membantu anak didik untuk bisa mengerti kekuatan dan kelebihan mereka yang sesuai dengan gaya belajar mereka masing-masing, karena proses pembelajaran terkait yang dapat diberikan kepada para siswa adalah suatu proses pembelajaran yang diawali dengan menggali dan mengerti kebutuhan anak didik (Gunawan, 2006).

\section{Strategi Genius Learning}

Gunawan (2006) mengemukakan bahwa Genius Learning atau lebih tepat disebut sebagai
Holistic Learning adalah istilah yang digunakan untuk menjelaskan suatu rangkaian pendekatan praktis dalam upaya meningkatkan hasil proses pembelajaran. Upaya peningkatan ini dicapai dengan menggunakan pengetahuan yang dicapai dengan berbagai disiplin ilmu seperti pengetahuan tentang cara kerja otak, cara kerja memori, neuro-linguistik programming, motivasi, konsep diri, kepribadian, emosi, perasaan, pikiran, metakognisi, gaya belajar, multiple intelligence atau kecerdasan jamak, teknik memori, teknik membaca, teknik mencatat, dan teknik belajara lainnya. Konsep Genius Learning mengacu ke konsep dasar metode Accelareted Learning atau metode belajar yang dipercepat yang dikembangkan oleh Dr. Georgi Lozanov. Metode Genius Learning adalah memasukkan dan memertimbangkan kondisi masyarakat Indonesia secara umum, kebudayaan bangsa kita yang sangat beragam, kondisi sosial dan ekonomi, sistem pendidikan nasional kita dan tujuan pendidikan yang utama yaitu untuk menyiapkan anak-anak untuk menjalani hidupnya dengan berhasil setelah meninggalkan sekolah formal dan masuk ke universitas kahidupan.

Strategi Genius Learning menurut Gunawan menekankan 9 prinsip utama dalam proses pembelajaran, yaitu:

1. Otak akan berkembang dengan maksimal dalam lingkungan yang kaya akan stimulus multi sensori dan tantangan berpikir.

2. Besarnya pengharapan/ekspektasi berbanding lurus dengan hasil yang dicapai.

3. Lingkungan belajar yang "aman" adalah lingkungan belajar yang memberikan tantangan tinggi namun dengan tingkat ancaman yang rendah.

4. Otak sangat membutuhkan umpan balik yang bersifat segera dan mempunyai banyak pilihan.

5. Musik membantu proses pembelajaran.

6. Ada berbagai alur dan jenis memori yang berbeda yang berada pada otak kita.

7. Kondisi fisik dan emosi saling berkaitan dan tidak dapat dipisahkan. 
8. Setiap otak adalah unik dengan kapasitas pengembangan yang berbeda berdasarkan pengalman pribadi.

9. Walaupun terdapat perbedaan fungsi antara otak kiri dan kanan, namun kedua belah hemister ini bisa bekerja sama dalam mengelola suatu informasi.

Dapat dilakukan self test atau test yang dilakukan oleh murid sendiri terhadap pemahamannya. Bisa juga digunakan pengujian dengan cara berpasangan dengan rekan murid yang lainnya. Intinya adalah menciptakan suasana yang menyenangkan dan bebas dari stress saat anda melakukan test. Dapat juga dilakukan beberapa teknik tambahan yang dapat digunakan guru dalam melakukan proses peninjauan ulang /pengulangan dan penjangkaran: penutup sesi pembelajaran, membicarakan topik, ngobrol santai, donat, rotasi refleksi, operan kertas ide, komentar penutup.

Pada setiap tahap pada pembelajaran dengan strategi Genius Learning, siswa dan guru bersama-sama aktif menjalani pembelajaran. Keaktifan guru dimaksudkan untuk memberi contoh dan membangun kemitraan dan komunikasi dengan siswa. Guru dapat mengetahui apakah ia melakukan pembelajaran sesuai dengan rencana yang disusun. Selain itu, guru juga melihat dan merasakan apa-apa yang terjadi dengan dan dalam pembelajarannya, apa yang dilakukan siswa. Keaktifan siswa akan dapat menyentuh badan, pikiran, ingatan, perasaan dan kesadarannya. Sentuhan pada kelima aspek tersebut mendorong terjadinya perkembangan yang seimbang pada semua dimensi potensi siswa.

\section{METODE PENELITIAN}

Penelitian dilaksanakan di SMP Swasta Raksana Medan Jln. Gajah Mada Medan. Waktu penelitian pada bulan Oktober 2009 semester I Tahun Pelajaran 2009/2010. Populasi penelitian adalah seluruh siswa kelas IX SMP Raksana Medan yang terdiri dari tiga kelas dengan jumlah siswa 120 orang. Sampel penelitian adalah kelas IX SMP Raksana Medan, sampel di ambil secara cluster random sampling. Kelas yang terpilih adalah kelas $\mathrm{IX}_{2}$ sebagai kelas eksperimen dan kelas $\mathrm{IX}_{3}$ sebagai kelas kontrol. Jenis penelitian yang digunakan adalah penelitian quasi eksperimen.

\section{Desain Penelitian}

Penelitian melibatkan dua kelas yang diberi perlakuan berbeda. Untuk mengetahui hasil belajar siswa yang di peroleh dengan penerapan dan perlakuan tersebut maka pada siswa diberikan tes. Dengan demikian rancangan penelitian ini adalah sebagai berikut:

\begin{tabular}{lccc}
\multicolumn{4}{c}{ Tabel 1. Rancangan Penelitian } \\
\hline Sampel & Pretes & Perlakuan & Postes \\
\hline Kelas control & $T_{1_{k}}$ & $\mathrm{X}_{1}$ & $T_{2_{k}}$ \\
\hline Kelas eksperimen & $T_{1_{e}}$ & $\mathrm{X}_{2}$ & $T_{2_{e}}$ \\
\hline
\end{tabular}

Keterangan:

$T_{1_{k}}=$ Pemberian tes awal (pretes) pada kelas kontrol

$T_{1_{e}}=$ Pemberian tes awal (pretes) pada kelas eksperimen

$T_{2_{k}}=$ Pemberian tes akhir (postes) pada kelas kontrol

$T_{2_{e}}=$ Pemberian tes akhir (postes) pada kelas eksperimen

$\mathrm{X}_{1}=$ Perlakuan 1 yang diberikan menggunakan pembelajaran konvensional

$\mathrm{X}_{2}=$ Perlakuan 2 yang diberikan dengan menggunakan strategi Genius Learning

\section{Analisis Data}

\section{Uji Normalitas}

Uji Nomalitas dalam penelitian menggunakan uji Liliefors dengan kriteria penerimaan apabila $L_{o}<L_{\text {tabel }}$ untuk $\alpha$ tertentu, sampel atau populasi yang diuji berdistribusi normal.

\section{Uji Homogenitas}

Uji homogenitas yang digunakan dalam penelitian ini adalah dengan uji $\mathrm{F}$ dengan rumus:

$$
F_{\text {hitung }}=\frac{\text { Varians terbesar }}{\text { Varians terkecil }}(\text { Sudjana, 2005) }
$$


Kriteria pengujiannya adalah apabila $F_{\text {hitung }}<$ $F_{\text {tabel }}$ maka $H_{o}$ diterima (homogen) dengan $\alpha$ yaitu 0,05 .

\section{Uji Hipotesis}

Menguji apakah terdapat perbedaan yang signifikan antara pretes kelas kontrol dan pretes kelas eksperimen dengan menggunakan uji $t$ untuk sampel tidak berhubungan, yaitu sebagai berikut:

$$
t=\frac{\bar{X}_{1}-\bar{X}_{2}}{S \sqrt{\frac{1}{n_{1}}+\frac{1}{n_{2}}}} \quad \text { (Sudjana, 2005) }
$$

Dengan standar deviasi gabungan:

$$
S=\frac{\left(n_{1}-1\right) S_{1}^{2}+\left(n_{2}-1\right) S_{2}^{2}}{n_{1}+n_{2}-2}
$$

Dengan keterangan:

$X_{1}=$ skor kelompol pertama

$X_{2}=$ skor kelompok kedua

$n_{1}=$ banyak skor yang dimiliki subjek kelompok pertama

$n_{2}=$ banyak skor yang dimiliki subjek kelompok kedua

$S=$ standar deviasi gabungan yang diperoleh dengan rumus

Jika $t_{\text {hitung }}>t_{\text {tabel }}$ maka $H_{a}$ diterima dan $H_{o}$ ditolak.

\section{HASIL PENELITIAN DAN PEMBAHASAN}

Hasil pemberian pretes pada kelas eksperimen diperoleh pada tabel berikut:

Tabel 1. Data Nilai Pretes Kelas Eksperimen

\begin{tabular}{cccc}
\hline No & $\begin{array}{c}\text { Nilai Pretes } \\
\text { Kelas }\end{array}$ & Rata-rata & $\begin{array}{c}\text { Standar } \\
\text { Deviasi }\end{array}$ \\
\hline 1. & Eksperimen & 25,875 & 7,835 \\
\hline 2. & Kontrol & 30,375 & 10,585 \\
\hline
\end{tabular}

\section{Hasil Postes Kelas Eksperimen dan Kontrol}

Hasil pemberian postes pada kelas eksperimen diperoleh pada tabel berikut:

Tabel 2. Data Nilai Postes Kelas Eksperimen

\begin{tabular}{cccc}
\hline No & $\begin{array}{c}\text { Nilai Postes } \\
\text { Kelas }\end{array}$ & $\begin{array}{c}\text { Rata- } \\
\text { rata }\end{array}$ & $\begin{array}{c}\text { Standar } \\
\text { Deviasi }\end{array}$ \\
\hline 1. & Eksperimen & 82,625 & 7,424 \\
\hline 2. & Kontrol & 60,125 & 12,062 \\
\hline
\end{tabular}

\section{Uji Persyaratan Analisa Data}

Uji persyaratan analisa data dilakukan dengan uji Normalisasi yaitu dengan uji liliefors, dan uji homogenitas varians diperolah. Tabel 3. Ringkasan Uji Normalitas Data

\begin{tabular}{|c|c|c|c|c|}
\hline No & Kelas & $L_{\text {hitung }}$ & $L_{\text {tabel }}$ & $\begin{array}{c}\text { Kesim- } \\
\text { pulan }\end{array}$ \\
\hline 1 & $\begin{array}{l}\text { Pretes } \\
\text { Eksperimen }\end{array}$ & 0,1377 & \multirow{4}{*}{0,1401} & \multirow{4}{*}{ Normal } \\
\hline 2 & $\begin{array}{l}\text { Pretes } \\
\text { Kontrol }\end{array}$ & 0,1370 & & \\
\hline 3 & $\begin{array}{l}\text { Postes } \\
\text { Eksperimen }\end{array}$ & 0,1368 & & \\
\hline 4 & $\begin{array}{l}\text { Postes } \\
\text { Kontrol }\end{array}$ & 0,1128 & & \\
\hline
\end{tabular}
Dengan Uji Liliefors

Berdasarkan data dari tabel 3 menunjukkan bahwa $L_{\text {hitung }}<L_{\text {tabel }}$. Hal ini menunjukkan bahwa kedua kelompok data terdistribusi normal.

\section{Uji Homogenitas}

Untuk menguji perbedaan hasil belajar perlu diketahui apakah data memenuhi asumsi sampel berasal dari varians yang homogen maka diperlukan uji kesamaan dua varians. Pada masing-masing data pretes dan postes untuk kedua sampel diperoleh pengujian $F_{\text {hitung }}$ $<F_{\text {tabel }}$ maka diterima hipotesis nol bahwa sampel memiliki varians yang homogen. Ringkasan Uji Homogenitas kelas Eksperimen dan kelas Kontrol sebagai berikut:

Tabel 4. Ringkasan Uji Homogenitas Varians

\begin{tabular}{clcccc}
\hline No & Data Kelas & Varians & $F_{\text {hitung }}$ & $F_{\text {tabel }}$ & $\begin{array}{c}\text { Kesim- } \\
\text { pulan }\end{array}$ \\
\hline 1. & $\begin{array}{l}\text { Pretes } \\
\text { Eksperimen }\end{array}$ & 61,39 & & & \\
2. & $\begin{array}{l}\text { Pretes } \\
\text { Kontrol }\end{array}$ & 112,04 & 1,83 & & \\
\cline { 1 - 2 } 3 3. & $\begin{array}{l}\text { Postes } \\
\text { Eksperimen }\end{array}$ & 55,11 & & & \\
4. & $\begin{array}{l}\text { Postes } \\
\text { Kontrol }\end{array}$ & 145,49 & 2,64 & & $\begin{array}{c}\text { Homo- } \\
\text { gen }\end{array}$ \\
& & & & \\
\hline
\end{tabular}

Berdasarkan data tabel 4 menunjukan bahwa $F_{\text {hitung }}<F_{\text {tabel }}$. Hal ini menunjukkan bahwa kedua kelas sampel homogen.

\section{Pengujian Hipotesis}

Setelah data memenuhi persyaratan homogenitas dan normalitas, maka dilakukan 
pengujian hipotesis dalam penelitian ini dapat dilakukan dengan menguji perbedaan nilai postes kelas eksperimen dan kelas kontrol. Hasil uji $t$ diperoleh pada tabel 5 seperti dibawah ini.

Tabel 5. Ringkasan Perhitungan Uji Hipotesis

\begin{tabular}{llcccc}
\hline No & $\begin{array}{c}\text { Data Postes } \\
\text { Kelas }\end{array}$ & $\begin{array}{c}\text { Rata- } \\
\text { rata }\end{array}$ & $t_{\text {hitung }}$ & $t_{\text {tabel }}$ & Kesimpulan \\
\hline 1. & Eksperimen & 82,63 & & & Ada perbedaan \\
2. & Kontrol & 60,13 & 10,04 & 1,67 & yang signifikan \\
\hline
\end{tabular}

Berdasarkan data tabel dari tabel 5 diatas uji beda nilai postes kelas eksperimen dan nilai postes kelas kontrol diperoleh $t_{\text {hitung }}=10,04$ sedangkan $t_{\text {tabel }}=1,67$. Besarnya persentase peningkatan pengaruh penggunaan strategi genius learning di kelas eksperimen adalah $68,70 \%$, sedangkan besarnya pengaruh pembelajaran konvensional di kelas kontrol adalah 49,50\%. Ini menunjukkan bahwa ada pengaruh yang signifikan antara penggunaan strategi Genius Learning dengan pembelajaran konvensional terhadap hasil belajar siswa dalam pembelajaran.

\section{Aktivitas Siswa}

Pengamatan aktivitas dilakukan oleh seorang pengamat yang bertugas mengamati seluruh aktivitas siswa selama proses belajar mengajar berlangsung. Adapun aspek-aspek yang diamati adalah mengajukan pertanyaan, memberikan jawaban, membuat kesimpulan, menyampaikan ide. Pada kelas eksperimen aspek penilaian diatas diamati melalui beberapa kegiatan, yaitu: pada saat siswa mengambil kartu goal setting, tugas aktivasi, membuat kesimpulan melalui lingkaran donat dan diskusi kelompok. Namun pada kelas kontrol kegiatan yang menunjukkan adanya aktivitas siswa adalah melalui tanya jawab dan tugas yang diberikan kepada siswa. Hasil pengamatan aktivitas siswa dapat dilihat pada tabel di bawah ini:

Tabel 6. Pengamatan Aktivitas Siswa Kelas Eksperimen dan Kelas Kontrol

\begin{tabular}{clccc}
\hline No & Data Kelas & $\begin{array}{c}\text { Re-rata } \\
\text { Skor }\end{array}$ & $\begin{array}{c}\text { Re-rata } \\
\text { Nilai } \\
\text { Aktivitas }\end{array}$ & Kriteria \\
\hline 1. & Eksperimen & 12,50 & 78,125 & Baik \\
\hline 2. & Kontrol & 0,45 & 3,747 & $\begin{array}{c}\text { Sangat } \\
\text { Kurang }\end{array}$ \\
\hline
\end{tabular}

Berdasarkan tabel 6 diatas maka diketahui bahwa aktivitas siswa di kelas eksperimen dengan kriteria baik dan aktivitas siswa di kelas kontrol dengan kriteria sangat kurang.

\section{Pembahasan Hasil Penelitian}

Pada saat diberikan pretes, pencapaian tes hasil belajar siswa pada materi pokok listrik dinamis pada kelas eksperimen adalah 25,88 dan pada kelas kontrol 30,38, jadi kemampuan awal siswa pada kelas eksperimen dan kontrol adalah hampir sama. Kemudian dilakukan uji perbedaan untuk nilai pretes dan diperoleh $F_{\text {hitung }}=1,82<F_{\text {tabel }}=2,94$ maka disimpulkan bahwa kedua sampel memiliki varians yang homogen. Setelah dilakukan perlakuan yang berbeda diperoleh hasil belajar siswa dikelas eksperimen 82,63 sedangkan dikelas kontrol 60,13 . Dari hasil postes kedua sampel tersebut diperoleh selisih sebesar 22,50 sehingga terdapat perbedaan yang signifikan hasil belajar siswa pada kelas eksperimen dan kelas kontrol.

Besarnya pengaruh penggunaan strategi Genius Learning dalam pembelajaran fisika pada pokok bahasan Listrik Dinamis di kelas $\mathrm{IX}_{2}$ (kelas eksperimen) yaitu 68,7\%. Sedangkan besarnya pengaruh penggunaan pengajaran konvensional di kelas $\mathrm{IX}_{3}$ (kelas kontrol) yaitu 49,5\%. Dan aktivitas siswa di kelas eksperimen yang diajar dengan strategi Genius Learning memiliki penilaian aktivitas rata-rata 78,13 dengan kriteria baik. Sedangkan aktivitas siswa di kelas kontrol yang diajar dengan metode konvensional memiliki penilaian aktivitas ratarata 28,12 dengan kriteria sangat kurang baik.

Berdasarkan analisa diatas dapat diketahui, bahwa hasil belajar dan aktivitas siswa pada kelas eksperimen yang diberikan perlakuan dengan menggunakan strategi Genius Learning mengalami peningkatan yang lebih baik daripada kelas kontrol yang menggunakan pengajaran konvensional. Hal ini disebabkan siswa kelas eksperimen melakukan pembelajaran dengan strategi Genius Learning. Strategi Genius Learning dapat membantu siswa mempelajari konsep fisika. Dengan menggunakan strategi ini pembelajaran tidak terpusat 
pada guru. Siswa dituntut untuk lebih aktif dalam kegiatan belajar mengajar. Hasil belajar dan aktivitas siswa yang diajar dengan strategi Genius Learning sangat dipengaruhi oleh kegiatan-kegiatan yang diberikan kepada siswa yaitu, dengan memberikan kartu goal setting, tugas aktivasi, membuat kesimpulan dengan lingkaran donat, dan diskusi dalam kelompok.

Dengan kartu goal setting siswa lebih termotivasi untuk mengajukan pertanyaan, memberi jawaban atas pertanyaan teman atau guru, menyampaikan ide/pendapat, dan siswa juga lebih jujur apabila ada pelajaran yang tidak dimengerti selama proses pembelajaran. Dengan tugas aktivasi siswa lebih termotivasi untuk melakukan diskusi dan mengerjakan soal-soal yang diberikan guru kepada setiap kelompok siswa. Dengan demonstrasi siswa lebih mudah mengingat pelajaran karena setiap siswa diberi kesempatan untuk mendemonstrasikan pelajaran yang dipelajarinya baik perkelompok maupun perindividu. Dengan lingkaran donat siswa lebih mudah mengingat pelajaran yang telah diketahui sebelumnya dan pelajaran yang diketahuinya setelah belajar dikelas, siswa juga dapat membandingkan bagaimana pengetahuan awalnya dan pengetahuan setelah belajar dikelas.

\section{SIMPULAN}

Hasil belajar pada pokok bahasan Listrik Dinamis berdasarkan hasil perhitungan uji $t$ $(\alpha=0,05)$ didapat bahwa ada pengaruh yang signifikan penggunaan strategi Genius Learning terhadap hasil belajar siswa dan aktivitas siswa kelas IX semester I SMP Raksana Medan dalam pembelajaran Listrik Statis. Hal ini disebabkan strategi Genius Learning dapat membantu siswa mempelajari konsep fisika. Dengan menggunakan strategi Genius Learning pembelajaran tidak terpusat pada guru. Siswa dituntut untuk lebih aktif dalam kegiatan belajar mengajar karena dipengaruhi oleh kegiatan-kegiatan yang diberikan kepada siswa berupa memberikan kartu goal setting, tugas aktivasi, membuat kesimpulan dengan lingkaran donat, dan diskusi dalam kelompok.

\section{DAFTAR PUSTAKA}

Gunawan, A.W. 2006. Genius Learning Strategy. Jakarta: PT. Gramedia Pustaka Utama. . 2006. Born to be Genius. Jakarta: PT. Gramedia Pustaka Utama. Pandia, H. 2008. Peringkat Pendidikan Turun Dari 58 ke 62, http://epajak.org/abg/freemonitor-blog/ (diakses Mei 2009)

Sardiman, A.M. 2007. Interaksi Dan Motivasi Belajar-Mengajar. Jakarta: PT. Raja Grafindo Persada.

Sudjana. 2005. Metoda Statistika. Bandung: Tarsito. 